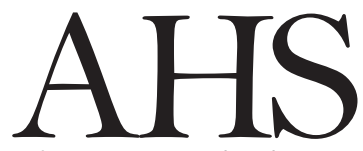

Advances in Horticultural Science

\title{
Investigation of modified WPM medium for the best meristem proliferation of Corylus avellana $\mathrm{L}$.
}

\author{
S. Kıvrak Kiran, S. Galatali, S. Yeniocak, D.E. Ozkaya, T. Mercan, S. \\ Guldag, O. Celik, N. Abdul Ghafoor, E. Kaya ${ }^{(*)}$ \\ Molecular Biology and Genetics Department, Faculty of Science, Mugla \\ Sitki Kocman University, 48000 Mugla, Turkey.
}

Key words: Charcoal, Fe-EDDHA, hazelnut, ISSR, micropropagation.
${ }^{(*)}$ Corresponding author:

ergunkaya@mu.edu.tr

Citation:

KIVRAK KIRAN S., GALATALI S., YENIOCAK S., OZKAYA D.E., MERCAN T., GULDAG S., CELIK O., ABDUL GHAFOOR N., KAYA E., 2021 -

Investigation of modified WPM medium for the best meristem proliferation of Corylus avellana $L$. - Adv. Hort. Sci., 35(3): 285-292

Copyright:

(c) 2021 Kivrak Kiran S., Galatali S., Yeniocak S., Ozkaya D.E., Mercan T., Guldag S., Celik O., Abdul Ghafoor N., Kaya E. This is an open access, peer reviewed article published by Firenze University Press (http://www.fupress.net/index.php/ahs/) and distributed under the terms of the Creative Commons Attribution License, which permits unrestricted use, distribution, and reproduction in any medium, provided the original author and source are credited.

Data Availability Statement:

All relevant data are within the paper and its Supporting Information files.

\section{Competing Interests:}

The authors declare no competing interests.

Received for publication 27 February 2021 Accepted for publication 29 June 2021
Abstract: Cultivation of Corylus avellana $L$. in Turkey is performed generally in the northern regions where it is an important source of livelihood for the local farmers. More than $\mathbf{7 0 \%}$ of world hazelnut production is supplied by Turkey, but compared with other countries, Turkey's hazelnut production area is quite narrow. In this study was aimed to develop an effective in vitro production for seven local cultivars of $C$. avellana. Therefore, WPM medium supplemented with 6-Benzylaminopurine (BAP) was modified by using single or in combination of Fe-EDDHA, $\mathrm{AgNO}_{3}, \mathrm{H}_{3} \mathrm{BO}_{3}$, charcoal and gibberellic acid. In all varieties, the best regeneration rates varying between $68 \%$ and $94 \%$ were obtained from WPM medium supplemented with 4.4 $\mu \mathrm{M}$ BAP, 27.8 $\mu \mathrm{M}$ Fe-EDDHA and 10g/L Charcoal. Genetic stability of shoots derived from meristem culture using the best medium was analysed using ISSR primers, when the gel images of the PCR products were examined, no polymorphic band was observed in samples collected from seven provinces, and the genetic stability was determined as $100 \%$.

\section{Introduction}

Corylus avellana L. plants are grown at altitudes in the range of 20$1500 \mathrm{~m}$ in the northern parts of the Turkey, they can also be grown in the southern and eastern creeks, and rarely in the western regions (Aydinoglu, 2010). Annual rainfall is balanced according to the seasons and temperatures, above $700 \mathrm{~mm}$ rainfall and temperatures ranging from $-8^{\circ} \mathrm{C}$ to $-10^{\circ} \mathrm{C}$ with the highest between $33^{\circ} \mathrm{C}$ and $36^{\circ} \mathrm{C}$ are ideal conditions for the production of C. avellana L. (Koksal et al., 2006). More than $70 \%$ of world hazelnut production is produced by Turkey (Zhao et al., 2015). However, Turkey's hazelnut production efficiency is very low compared to other countries. The average yield is $179.2 \mathrm{~kg} / \mathrm{ha}$ in the US, $168.6 \mathrm{~kg} / \mathrm{ha}$ in Italy whereas in Turkey it is $91.7 \mathrm{~kg} / \mathrm{ha}$ (Mennan et al., 2020; Sen and Kahveci, 2020).

The in vitro propagation procedures for clonal multiplication provide the useful alternative tools to traditional propagation of hazelnut cultivars. Development of an efficient procedure for hazelnut micropropagati- 
on can also be beneficial for increase of clones, cultivars and varieties resistant to different pathogens such as hazelnut worm (Curculio nucum), eastern filbert blight (Anisogramma anomola) and powdery mildew (Erysiphe corylacearum) (Bassil et al., 1992; Lucas et al., 2018).

The transfer of parts of the plant such as tissue, cell, organ, embryo to in vitro environment under aseptic conditions in an artificial nutrient medium for clonal propagation is important to produce a pathogen-free plant with protected germplasms and/or to maintain its secondary metabolites production which otherwise is limited for various reasons is called plant tissue culture (Hayta et al., 2017; Espinosa-Leal et al., 2018). In addition to the continuous production throughout the year by obtaining thousands of plants with the same form and characteristics as the mother plant in a short time by micropropagation method from plant tissue cultures; superior species resistant to factors such as drought, salinity, acidity, and/or cold can also be produced. Micropropagation involves plant selection, sterilization, in vitro transfer, clonal propagation, rooting, conditioning, and transfer to soil. Due to these advantages, micropropagation is one of the most effective methods when compared with other production techniques (Ozudogru et al., 2011; Ozudogru and Kaya, 2012).

Different techniques in plant tissue culture can be used such as shoot tip culture by transferring the shoot tips with growth cone including meristematic doom to in vitro environment, bud node culture by transferring the axillary or apical buds of the shoots to aseptic conditions, meristem culture by transferring meristem from the meristematic region to the nutrient medium with the help of a stereomicroscope, embryo culture by taking the embryo from the seed template or from the seed and transferring it to the germination medium (Ahmad and Anis, 2007; Usha et al., 2007).

Clonal production of plants in a short time is one of the main purposes of plant tissue culture, however, changes may occur in micropropagated plants, all the changes that may occur in the hereditary material are called somaclonal variation, somaclonal variations can be detected by various molecular tests (Samir, 2004; Lattoo et al., 2006; Ozudogru et al., 2011). Nowadays, genetic differences in the germplasms of many plant species can be detected using molecular markers, non-specific primers are often preferred in determining the differences between germplasms in methods based on the polymerase chain reaction, these primers are particularly advantageous for plant species that have not been previously studied or have a limited number of researches performed on them (Devarumath et al., 2002; Carvalho et al., 2004; Kaya and Souza, 2017). Although there are a wide variety of molecular marker techniques used nowadays, AFLP (Amplified Fragment Length Polymorphism), RAPD (Random Amplification of Polymorphic DNA), SSRs (Simple Sequence Repeats), ISSRs (Inter Simple Sequence Repeats) techniques are preferred. The method to be used is selected based on the technical facilities accessible and the purpose of the study (Belaj et al., 2003; Kaya, 2015).

The ISSR technique used in many plants is a simple, fast, and low-cost technique, it also stands out for its ability to work with a small amount of template DNA and provides a high level of information. With all these advantages, the ISSR technique is often preferred in determining the difference in germplasm collections (Gilbert et al., 1999; Kaya and Souza, 2017).

When there are some limitations (shoot tip necrosis, big contaminations, sensitivity for surface sterilization treatments) causing from plant material such as shoot tips, nodal segments, buds in in vitro propagation studies, seeds can be used as starting material and there are many similar studies in the literature such as micropropagation of Thymus vulgaris (Ozudogru et al., 2011), Citrus spp. (Kaya et al., 2016), Musa spp. (Kaya et al., 2020 b). Similarly, embryos isolated from hazelnut seeds were used as starting material in the current study, as there was a major contamination problem. Thus, the optimal growth medium developed for hazelnut these local varieties in the current study will be a model growth medium for future in vitro studies such as cryopreservation.

In this study, WPM nutrient medium developed by Lloyd and McCown which commonly used in micropropagation of woody plants in order to develop an effective environment for in vitro meristem reproduction of hazelnut plant, which is relatively difficult to micro-propagate due to some limitations was used (Lloyd and McCown, 1980). The main aim of this study was to determine optimal medium combination by using WPM. Seven different cultivars of hazelnuts grown in seven different provinces of Turkey were examined with different combinations of Benzyl Amino Purine and Gibberellic Acid growth regulators, ethylene diamine di-2-hydroxyphenyl acetate ferric 
(Fe-EDDHA), Silver nitrate $\left(\mathrm{AgNO}_{3}\right)$, boric acid $\left(\mathrm{H}_{3} \mathrm{BO}_{3}\right)$ and activated charcoal. In addition, the another aim was to confirmation genetic stability of in vitro grown plants. For this reason, the genetic stability of the plants growing in in vitro conditions that gave the best results in the study was analysed by the ISSR technique.

\section{Materials and Methods}

In vitro culture initiation and micropropagation

C. avellana L. plant samples (fruits) from Turkey's; Bartin (Guzelcehisar Village, Inkumu location), Düzce (Akcakoca, Yesilkoy Village), Trabzon (Ortahisar, Yanyamac location), Ordu (Ulubey, Inonu location), Samsun (Carsamba, Ordubasi District), Giresun (Eriklimanı Village), and Zonguldak (Eregli, Sarikaya Village) (seven different) provinces were obtained from their respective hazelnut breeders. The fruits were surface sterilized to remove pathogens before transfer to the in vitro medium using $70 \%$ Ethanol (EtOH) and 30\% Commercial Bleach (Domestos, Unilever $\left.{ }^{\odot}\right)$. This step was followed by 3-stage internal sterilization $\left(70 \% \mathrm{EtOH}, 10 \% \mathrm{H}_{2} \mathrm{O}_{2}\right.$, and $10 \%$ Commercial Bleach) processes applied to the materials separated from their peels with the help of sterile forceps and pliers (Ozudogru et al., 2011; Kaya et al., $2013,2016)$. After the sterilization processes, embryo isolation was performed from $C$. avellana L. samples under a stereomicroscope in a laminar flow cabinet (Fig. $1 \mathrm{a}$ ), the isolated embryos were then transferred to WPM semi-solid medium containing $4.44 \mu \mathrm{M} 6$ Benzilaminopurin (BA), $30 \mathrm{~g} / \mathrm{L}$ sucrose and $7 \mathrm{~g} / \mathrm{L}$ agar for germination ( $\mathrm{pH}$ 5.8). The germinated embryos were taken into WPM medium supplemented with $4.44 \mu \mathrm{M}$ BA $30 \mathrm{~g} \mathrm{~L}^{-1}$ sucrose, $7 \mathrm{~g} \mathrm{~L}^{-1}$ agar and $27.8 \mu \mathrm{M}$ Fe-EDDHA [Ethylenediamine-N, N'-bis (2-hydroxyp-

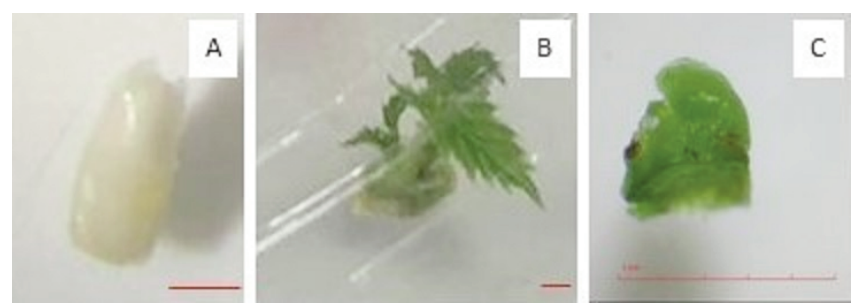

Fig. 1 - The embryo was isolated from fruit of $C$. avellana L. cv. Duzce-Akcakoca $(A)$, the embryo germination on WPM semi-solid medium containing $4.44 \mu \mathrm{M}$ BAP $30 \mathrm{~g} \mathrm{~L}^{-1}$ sucrose and $7 \mathrm{~g} \mathrm{~L}^{-1}$ agar $27.8 \mu \mathrm{M}$ Fe-EDDHA (B), the meristem was isolated from in vitro grown shoot of $C$. avellana L. cv. Duzce-Akcakoca (C) (Bars $1 \mathrm{~mm}$ ). henylacetic acid) iron sodium complex] (Fig. 1 b). In order to determine the suitable medium for the hazelnut plant, the meristematic regions of $0.3-0.8$ $\mathrm{mm}$ length of shoots of the seven different hazelnut varieties grown in vitro were isolated (Fig. 1c) and transferred to eight different modified WPM mediums (Table 1). The all in vitro materials were incubated at standard culture conditions $\left(27 \pm 2^{\circ} \mathrm{C}, 16 / 8 \mathrm{~h}\right.$ photoperiod, with cool daylight fluorescent lamps rated at $\left.50 \mathrm{\mu mol}^{-1} \mathrm{~m}^{-2} \mathrm{~s}^{-1}\right)$.

Table 1 - Eight different modified WPM mediums for in vitro meristem proliferation of seven Corylus avellana L. cultivars

\begin{tabular}{|c|c|c|}
\hline Medium & $\begin{array}{l}\text { Plant growth } \\
\text { regulator }\end{array}$ & Chemical \\
\hline WPM 1 & $4.44 \mu \mathrm{M} \mathrm{BA}$ & $27.8 \mu \mathrm{M}$ Fe-EDDHA \\
\hline \multirow[t]{2}{*}{ WPM 2} & $4.44 \mu \mathrm{M} B A$ & $27.8 \mu \mathrm{M}$ Fe-EDDHA \\
\hline & $2.89 \mu \mathrm{M} \mathrm{GA}_{3}$ & \\
\hline \multirow[t]{2}{*}{ WPM 3} & $4.44 \mu \mathrm{M} B A$ & $27.8 \mu \mathrm{M}$ Fe-EDDHA \\
\hline & & $5.89 \mu \mathrm{M} \mathrm{AgNO}{ }_{3}$ \\
\hline \multirow[t]{2}{*}{ WPM 4} & $4.44 \mu \mathrm{M} B A$ & $27.8 \mu \mathrm{M}$ Fe-EDDHA \\
\hline & & $16.17 \mu \mathrm{M} \mathrm{H}_{3} \mathrm{BO}_{3}$ \\
\hline \multirow[t]{2}{*}{ WPM 5} & $4.44 \mu \mathrm{M} B A$ & $27.8 \mu \mathrm{M}$ Fe-EDDHA \\
\hline & & $10 \mathrm{~g} \mathrm{~L}^{-1}$ Charcoal \\
\hline \multirow[t]{2}{*}{ WPM 6} & $4.44 \mu \mathrm{M} B A$ & $27.8 \mu \mathrm{M}$ Fe-EDDHA \\
\hline & $2.89 \mu \mathrm{M} \mathrm{GA}_{3}$ & $10 \mathrm{~g} \mathrm{~L}^{-1}$ Charcoal \\
\hline \multirow[t]{3}{*}{ WPM 7} & $4.44 \mu \mathrm{M}$ BA & $27.8 \mu \mathrm{M}$ Fe-EDDHA \\
\hline & & $5.89 \mu \mathrm{M} \mathrm{AgNO}$ \\
\hline & & $10 \mathrm{~g} \mathrm{~L}^{-1}$ Charcoal \\
\hline \multirow[t]{3}{*}{ WPM 8} & $4.44 \mu \mathrm{M}$ BA & $27.8 \mu \mathrm{M}$ Fe-EDDHA \\
\hline & & $16.17 \mu \mathrm{M} \mathrm{H}_{3} \mathrm{BO}_{3}$ \\
\hline & & $10 \mathrm{~g} \mathrm{~L}^{-1}$ Charcoal \\
\hline
\end{tabular}

\section{Determination of genetic stability}

In order to determine the effects of the modified WPM nutrient medium that gives the best regeneration with the meristem culture method on the genetic stability of the plant, DNA isolation was performed manually following the $2 \times$ CTAB protocol developed by Ferdous et al. (2012). Following the DNA isolation, the protocol developed by Williams et al. (1990) was used with the ISSR primers developed by MartinsLopes et al. (2007) [(TC) 8C UBC823; (GA) 8C UBC811; (AG) 8G UBC809; (CA) 8A UBC817; (AG) 8T UBC807; (GA) 8T UBC810] to perform an ISSR PCR reaction. The products obtained from the ISSR PCR were run on an agarose gel electrophoresis containing 1.5\% agarose and the bands profiles were visualized under UV-transilluminator. The "Similarity Ratio" formula developed by Sokal and Sneath (1963) was used to 
calculate the similarities between the samples in determining the genetic stability or differences as a result of data analysis by scoring the band profiles displayed as a result of ISSR PCR according to the $1 / 0$ (yes/no) principle.

\section{Similarity ratio $=$ Homologous bands $/($ Homologous bands + Non homologous bands)}

The DNA of the samples were obtained from in vitro embryo-grown leaves (in WPM medium supplemented with $4.44 \mu \mathrm{M} \mathrm{BA}$ ), leaves of shoots that developed after subculture (in WPM medium containing $4.44 \mu \mathrm{M}$ BA and $27.8 \mu \mathrm{M}$ Fe-EDDHA), and postmeristem culture grown shoot leaves (in WPM medium containing 4.44 $\mu \mathrm{M}$ BA, $27.8 \mu \mathrm{M}$ Fe-EDDHA and $10 \mathrm{~g} \mathrm{~L}^{-1}$ charcoal) were used.

Experimental design, data collection, and statistical analysis

For each cultivar, more than 100 embryos of seeds were used for in vitro culture establishment. Three Petri dishes (replicates), each containing 10 shoot tips, were used for each in vitro proliferation treatment, and each experiment was repeated at least three times. Data of in vitro proliferation were recorded 4 weeks after culture initiation and consisted of the percentage of shoot tips that generated at least one elongated shoot. Regeneration percentage was compared by multiple X2 test by the SPSS program (IBM SPSS Statistics 21.0) and statistical analysis was also performed with ANOVA, followed by the LSD test at $P \leq 0.05$ (Marascuilo and McSweeney, 1977).

\section{Results}

After surface sterilization, the embryos germinated in WPM medium containing $4.44 \mu \mathrm{M}$ BAP were transferred to the regeneration medium, from the samples that were used as starting material, $71 \%$ to $85 \%$ sterile material was obtained as a result of surface sterilization. The obtained clean materials showed successful regeneration between $81.1 \%$ and $100 \%$. Shoot tips grown in vitro were subcultured, and reproduced in 30-day periods, and used as the material in meristem culture study. The desired amount of in vitro material was obtained from regenerated plants for use in meristem culture applications.

The best regeneration rate from eight different WPM media in different combinations tested for meristem regeneration was obtained from WPM media containing 4.44 $\mu \mathrm{M}$ BAP, $27.8 \mu \mathrm{M}$ Fe-EDDHA, and $10 \mathrm{gL}^{-1}$ charcoal. The regeneration rate obtained on this medium ranged from $68 \%$ to $94 \%$ for the seven hazelnut local cultivars tested (Fig. 2).

Polymerase chain reactions were carried out using six different primers to determine the genetic stability of regenerated hazelnut varieties. In order to determine genetic stability, clones of each sample developed from a single embryo were used. PCR products obtained from the PCR using six different ISSR primers were run on an agarose gel and visualized. A total of 324 bands with a length of $120 \mathrm{bp}$ and 2800 bp were scored from the band profiles obtained. In the light of the band profiles obtained, no polymorphic bands were observed in samples collected from the seven provinces, and the genetic stability was determined as $100 \%$ (Fig. 3).

\section{Discussion and Conclusions}

In Turkey, for hazelnut production, the certified seedlings have not still been studied and conventional production does not meet all requirements of Hazelnut plants. Because these plant cultivars can be affected very quickly by climatic conditions and fruit

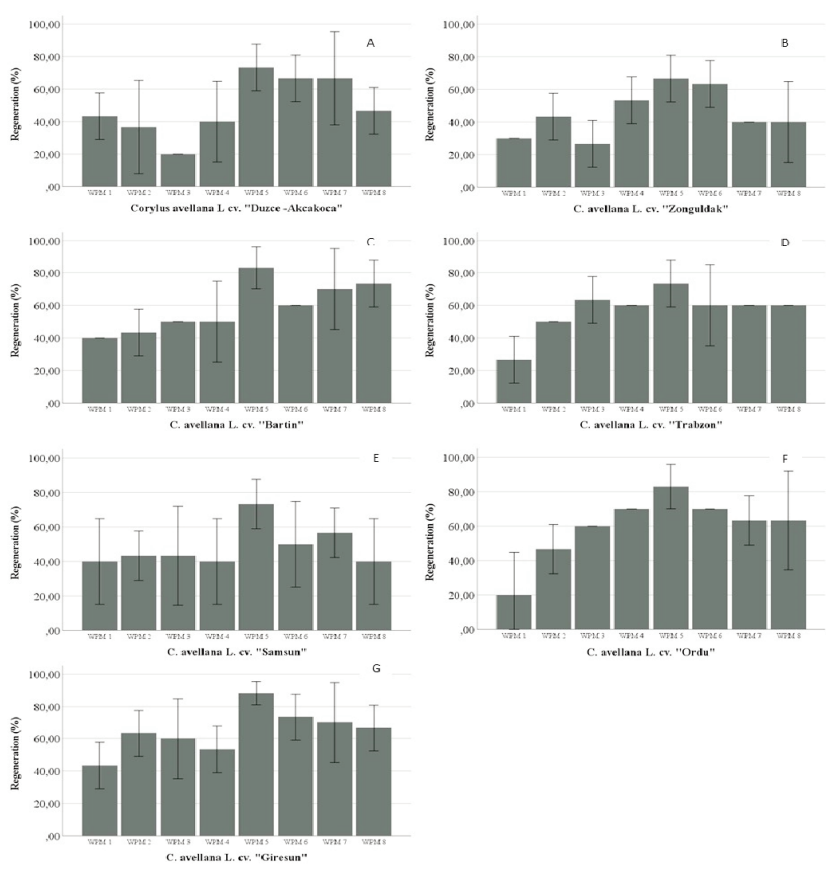

Fig. 2 - The meristem regeneration percentages of seven different cultivars of $C$. avellana L. on eight different modified WPM mediums. 


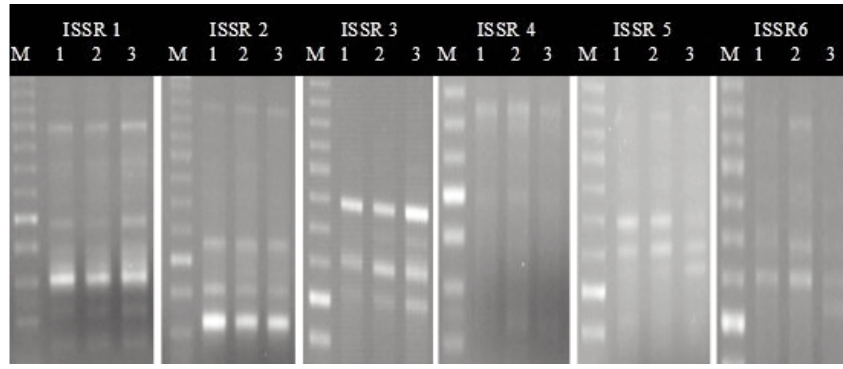

Fig. 3 - The interaction effect of different rootstocks and $\mathrm{NO}_{3}: \mathrm{NH}_{4}$ ratio on $\mathrm{A}$ ) number of leaves and $\mathrm{B}$ ) number of nodes.

yield may decrease accordingly, physical factors such as the reduction in the mineral and organic matter content of the soil, and biological factors such as hazelnut pests and diseases can further decrease its yield. In this case, it is extremely important to examine the factors that cause low productivity and to determine the measures that could eliminate these factors or reduce their effect (Amaral et al., 2006; Aydinoglu, 2010; Ciarmiello et al., 2014).

Increasing trends in areas such as the development of systems for densely planting tree seedlings, selection of new parents for nutrition programs, development of new cultures in order to better evaluate the existing limited areas, increased the need for modern techniques in fruit tree cultivation. Traditional methods, which were carried out to meet the demand for more high-quality plant material are insufficient for they are both time consuming and insufficient for standard and healthy production, therefore, the application of in vitro techniques in fruit growing may be a suitable alternative way to overcome these problems. Developments in plant biotechnology, particularly in the fields of in vitro cultures and molecular biology, have been a powerful tool in the control and conservation of plant biodiversity (Withers, 1995). Nowadays, biotechnological methods comprise the most suitable methods for pathogen-free short, medium, and long-term protection of ornamental, medicinal, and aromatic plants as well as woody plant species, which are in danger of extinction and poses rare economical value. In vitro conservation methods are especially important for the protection of vegetatively propagated plant species with seeds that are intolerant to desiccation (Engelmann, 2011). In addition to the advantages mentioned above, in vitro techniques provide a reliable platform for international plant material exchange, enable large collections using minimal space, provide valuable materials for species recovery, and facilitate molecular research and ecological studies (Tandon et al., 2005).

Traditional propagation procedures for hazelnut through shoots is time consuming, limited and inefficient for large scale production. These days, many hazelnut cultivars have been identified for plantation in Turkey and it immediately needs to develop efficient procedures for rapid clonal propagation. The plant tissue culture systems offer an useful tools for large scale production of plantlets (Damiano et al., 2005; Bacchetta et al., 2008). The current study aimed to develop and integrated procedure to clonal propagation of Turkish local hazelnut cultivars with optimal combination of growth media supplemented with plant growth regulators/additives in tissue culture techniques.

Meristem culture has been used for the purification of pathogens from plants since the 1930s (Dodds and Roberts, 1986; Nehra and Kartha, 1994). In this technique, the difference in the amount of pathogens in different plant cells is utilized such that the apical and root meristem cells of the plant are very small due to their continuous division characteristics hence the probability of viruses in these cells is very low, therefore, these tissues are highly preferred in the production of pathogen-free and/or disease-free plants (Kaya et al., 2020 a). Although it cannot be stated that these parts of the plant are completely free from viruses, the probability can be increased when applying different treatment combinations together (Sherwood, 1993). In this study, meristem culture examinations were carried out using meristematic regions of length between 0.1-0.8 mm extracted from axenic (virus-free) shoots of plants belonging to hazelnut varieties collected from seven different provinces that were grown in vitro using clonal propagation. The micro-shoots regenerated in vitro were subcultured in 4-6 week periods at standard conditions and the best regeneration rate among the eight different WPM media containing different ingredient combinations tested for meristem regeneration was obtained from WPM medium containing $4.44 \mu \mathrm{M}$ BAP, $27.8 \mu \mathrm{M}$ Fe-EDDHA and activated charcoal, and the regeneration rate obtained on this medium was between $68 \%$ and $94 \%$ for seven different hazelnut local cultivars tested.

The iron component of medium is an essential micronutrient for Hazelnut in vitro cultures and these cultures can also be very sensitive to the iron source and concentration. In in vitro cultures of hazelnut, beneficial effect of Fe-EDDHA as source of iron, have 
been reported in previous studies (Nas and Read, 2001; Garrison et al., 2013). In the current study, the significant multiplication rates in hazelnut local cultivars were achieved by using medium supplemented with Fe-EDDHA as iron source.

In the current study, the media supplemented with activated charcoal showed the beneficial effect on in vitro cultures of all hazelnut local cultivars. In in vitro cultures, because of their absorbtion ability (growth regulators, inhibitors, other compounds), the activated charcoal can promote growth (Pan and Staden, 1998).

Morphological differences that make up biological and pharmaceutical characters are under the influence of environmental and/or genetic factors (Hay and Waterman, 1995). In recent years, DNA-based molecular markers have been used to determine genetic differences in the germplasms of many plant species, the use of various DNA markers in plant research has become increasingly common as they provide a larger number of markers than allozymes. In various DNA-based PCR methods, mostly non-specific primers are used to determine the differences between (and within) species. These methods, which are preferred because they do not require sequence knowledge in target species, are particularly suitable for plant varieties on which none or very little research has been done before (Walton, 1993).

In this study, the genetic stability of hazelnut samples collected from seven different provinces after meristem culture was evaluated by PCR using six different ISSR primers. Polymorphism was not detected in the cultivars as a result of visualizing the PCR products in agarose gel. In this context, we can say that the nutrient medium optimized for meristem culture does not have a negative effect on the genetic stability of the hazelnut varieties tested.

It is known that plants propagated in vitro by shoot tip, axillary bud, and meristems, maintain their genetic stability during cell division and differentiation under in vitro conditions (Shenoy and Vasil, 1992; Ostry et al., 1994). However, it should not be overlooked as there is a risk of alteration of genetic stability induced during the in vitro applications (types and concentrations of growth regulators, nutrient conditions). There are many studies in the literature regarding this (Rani et al., 1995; Giménez et al., 2001), these changes in genetic stability are often inherited and can be passed down from generation to generation during micropropagation (Breiman et al., 1987).

\section{Acknowledgements}

This study was supported by Mugla Sitki Kocman University, Scientific Research Projects Coordination Unit (Mugla, Turkey, MSKU-BAP, Project Number: 17057).

\section{References}

AHMAD N., ANIS M., 2007 - Rapid clonal multiplication of a woody tree, Vitex negundo L. through axillary shoots proliferation. - Agro Syst., 71: 195-200.

AMARAL J.S., CUNHA S.C., SANTOS A., 2006 - Influence of cultivar and environmental conditions on the triacylglycerol profile of hazelnut (Corylus avellana L.). - J. Agric. Food Chem., 54(2): 449-456.

AYDINOGLU A.C., 2010 - Examining environmental condition on the growth areas of Turkish hazelnut (Corylus colurna L.). - Afr. J. Biotechnol., 9(39): 6492-6502.

BACCHETTA L., ARAMINI M., BERNARDINI C., RUGINI E., 2008 - In vitro propagation of traditional Italian hazelnut cultivars as a tool for the valorization and conservation of local genetic resources. - HortSci., 43(2): 562566.

BASSIL N., MOK D.W.S., MOK M.C., REBHUHN B.J., 1992 Micropropagation of the hazelnut, Corylus avellana. Acta Horticulturae, 300: 137-140.

BELAJ A., SATOVIC Z., CIPRIANI G., BALDONI L., TESTOLIN R., RALLO L., TRUJILLO I., 2003 - Comparative study of the discriminating capacity of RAPD, AFLP and SSR markers and of their effectiveness in establishing genetic relationships in olive. - Theor. Appl. Genet., 107(4): 736-744.

BREIMAN A., ROTEM-ABARBANELL D., KARP A., SHASKIN, H., 1987 - Heritable somaclonal variation in wild barley (Hordeum spontaneum). - Theor. Appl. Genet., 74(1): 104-112.

CARVALHO L.C., GOULÃO L., OLIVEIRA C., GONÇALVES J.C., AMÂNCIO S., 2004 - RAPD assessment for identification of clonal identity and genetic stability of in vitro propagated chestnut hybrids. - Plant Cell Tissue Organ Cult., 77: 23-27.

CIARMIELLO L.F., MAZZEO M.F., MINASI P., PELUSO A., DE LUCA A., PICCIRILLO P., SICILIANO R.A., CARBONE V., 2014 - Analysis of different European hazelnut (Corylus avellana L.) cultivars: Authentication, phenotypic features, and phenolic profiles. - J. Agric. Food Chem., 62(26): 6236-6246.

DAMIANO C., CATERNARO J., GIOVINAZZI J., FRATARELLI A., CABONI E., 2005 - Micropropagation of hazelnut (Corylus avellana L.). - Acta Horticulturae, 686(1): 221226.

DEVARUMATH R.M., NANDY S., RAVI V., MARIMUTHU S., MURALEEDHARAN N., RAINA S.N., 2002 - RAPD, ISSR 
and RFLP fingerprints as useful markers to evaluate genetic integrity of micropropagated plants of three diploid and triploid elite tea clones representing Camellia sinensis (China type) and C. assamica ssp. assamica (Assam-India type). - Plant Cell Rep., 21: 166173.

DODDS J.H., ROBERTS L.W., 1986 - Experiment in plant tissue culture - Cambridge University Press, USA, pp. 113121.

ENGELMANN F., 2011 - Use of biotechnologies for the conservation of plant biodiversity. - In Vitro Cell Dev. Biol. Plant, 47(1): 5-16.

ESPINOSA-LEAL C.A., PUENTE-GARZA C.A., GARCÍA-LARA S., 2018 - In vitro plant tissue culture: means for production of biological active compounds. - Planta, 248: 1-18.

FERDOUS J., HANAFI M.M., RAFII M.Y., MUHAMMAD K., 2012 - A quick DNA extraction protocol: Without liquid nitrogen in ambient temperature. - Afr. J. Biotechnol., 11(27): 6956-6964.

GARRISON W., DALE A., SAXENA P.K., 2013 - Improved shoot multiplication and development in hybrid hazelnut nodal cultures by ethylenediamine di-2-hydroxyphenylacetic acid (Fe-EDDHA). - Can. J. Plant Sci., 93(3): 511-521.

GILBERT J.E., LEWIS R.V., WILKINSON M.J., CALIGARI P.D.S., 1999 - Developing an appropriate strategy to assess genetic variability in plant germplasm collections. Theor. Appl. Genet., 98(6-7): 1125-1131.

GIMÉNEZ C., DE GARCIA E., DE ENRECH N.X., BLANCA I., 2001 - Somaclonal variation in banana: cytogenetic and molecular characterization of the somaclonal variant CIEN BTA-03. - In Vitro Cell Dev. Biol. Plant., 37(2): 217222.

HAY R.K.M., WATERMAN P.G., 1995 - Volatile oil crops: Their biology, biochemistry and production. - Longman Scientific and Technical, Wiley-Blackwell, pp. 200.

HAYTA S., BAYRAKTAR M., BAYKAN EREL S., GUREL A., 2017 - Direct plant regeneration from different explants through micropropagation and determination of secondary metabolites in the critically endangered endemic Rhaponticoides mykalea. - Plant Biosyst. Int. J. Deal. Asp. Plant. Biol., 151: 20-28.

KAYA E., 2015 - ISSR analysis for determination of genetic diversity and relationship in some Turkish olive (Olea europaea L.) cultivars. - Not. Bot. Hort. Agrobot. Cluj., 43(1): 96-99.

KAYA E., ALVES A., RODRIGUES L., JENDEREK M., HERNANDEZ-ELLIS M,. OZUDOGRU A., ELLIS D., 2013 Cryopreservation of Eucalyptus genetic resources. Cryo-Lett., 34(6): 608-618.

KAYA E., GALATALI S., GULDAG S., CELIK O., 2020 a - A new perspective on cryotherapy: pathogen elimination using plant shoot apical meristem via cryogenic techniques, pp. 137-148. - In: NASEEM M.T, DANDEKAR (eds.).
Plant stem cells. Methods in molecular biology. Volume 2094. Humana, New York, USA, pp. 150.

KAYA E., SOUZA F.V.D., 2017 - Comparison of two PVS2based procedures for cryopreservation of commercial sugarcane (Saccharum spp.) germplasm and confirmation of genetic stability after cryopreservation using ISSR markers. - In Vitro Cell Dev. Biol. Plant, 53(4): 410417.

KAYA E., SOUZA F.V.D., SANTOS-SEREJO J., GALATALI S., $2020 \mathrm{~b}$ - Influence of dehydration on cryopreservation of Musa spp. germplasm. - Acta Bot. Croat., 79(2): 99104.

KAYA E., SOUZA F.V.D., YILMAZ-GOKDOGAN E., CEYLAN M., JENDEREK M., 2016 - Cryopreservation of citrus seed via dehydration followed by immersion in liquid nitrogen. - Turk. J. Biol., 41: 242-248.

KOKSAL I., ARTIK N., SIMSEK A., GUNES N., 2006 - Nutrient composition of hazelnut (Corylus avellana L.) varieties cultivated in Turkey. - Food Chem., 99(3): 509-515.

LATTOO S.K., BAMOTRA S., DHAR R.S., KHAN S., DHAR A.K., 2006 - Rapid plant regeneration and analysis of genetic fidelity of in vitro derived plants of Chlorophytum arundinaceum Baker-an endangered medicinal herb. - Plant Cell Rep., 25: 499-550.

LLOYD G., MCCOWN B.H., 1980 - Commercially feasible micropropagation of mountain laurel (Kalmia latifolia) by use of shoot tip culture. - Int. Plant Prop. Soc. Comb. Proc., 30: 421-427.

LUCAS S.J., SEZER A., BOZTEPE O., KAHRAMAN K., BUDAK H., 2018 - Genetic analysis of powdery mildew disease in Turkish hazelnut. - Acta Horticultare, 1226: 413-420.

MARASCUILO L.A., MCSWEENEY M., 1977 - Post-hoc multiple comparisons in sample preparations for test of homogeneity, pp. 141-147. - In: MCSWEENEY M., and L.A. MARASCUILO (eds.) Non-parametric and distribution-free methods for the social sciences. Brooks/Cole Publications, Pacific Grove, CA, USA.

MARTINS-LOPES P., LIMA-BRITO J., GOMES S., MEIRINHOS J., SANTOS L., GUEDES-PINTO H., 2007 - RAPD and ISSR molecular markers in Olea europaea L.: Genetic variability and molecular cultivar identification. - Genet. Resour. Crop Ev., 54(1): 117-128.

MENNAN H., BOZOGLU M., BASER U., BRANTS I., BELVAUX X., KAYA ALTOP E., ZANDSTRA B.H., 2020 - Impact analysis of potential glyphosate regulatory restrictions in the European Union on Turkish hazelnut production and economy. - Weed Sci., 68(3): 223-231.

NAS M.N., READ P.E., 2001 - Micropropagation of hybrid hazelnut: Medium composition, physical state and iron source affect shoot morphogenesis, multiplication and explant vitality. - Acta Horticulturae, 556(36): 252-257.

NEHRA N.S., KARTHA K.K., 1994 - Meristem and shoot tip culture: Requirements and Applications, pp. 37-70. - In: VASIL I.K., and T.A. THORPE (eds.) Plant cell and tissue Culture. Kluwer Academic Publishers, Dordrecht, The 
Netherlands.

OSTRY M., HACKETT W., MICHLER C., SERRES R., MCCOWN B., 1994 - Influence of regeneration method and tissue source on the frequency of somatic variation in Populus to infection by Septoria musiva. - Plant Sci., 97(2): 209215.

OZUDOGRU E.A., KAYA E., 2012 - Cryopreservation of Thymus cariensis and T. vulgaris shoot tips: comparison of three vitrification-based methods. - Cryo-Lett., 33(5): 363-375.

OZUDOGRU E.A., KAYA E., KIRDOK E., ISSEVER-OZTURK S., 2011 - In vitro propagation from young and mature explants of thyme (Thymus vulgaris and T. longicaulis) resulting in genetically stable shoots. - In Vitro Cell Dev. Biol. Plant., 47(2): 309-320.

PAN M., STADEN J.V., 1998 - The use of charcoal in in vitro culture - A review. - Plant Growth Regul., 26: 155-163.

RANI V., PARIDA A., RAINA S.N., 1995 - Random amplified polymorphic DNA (RAPD) markers for genetic analysis in micropropagated plants of Populus deltoides Marsh. - Plant Cell Rep., 14(7): 459-462.

SAMIR C.D., 2004 - Clonal propagation of dwarf raspberry (Rubus pubescens Raf.) through in vitro axillary shoot proliferation. - Plant Growth Regul., 43: 179-186.

SEN D., KAHVECI D., 2020 - Production of a protein concentrate from Hazelnut meal obtained as a hazelnut oil industry by-product and its application in a functional beverage. - Waste Biomass Valor., 11: 5099-5107.

SHENOY V.B., VASIL I.K., 1992 - Biochemical and molecular analysis of plants derived from embryogenic tissue cultures of napier grass (Pennisetum purpureum $\mathrm{K}$.
Schum). - Theor. Appl. Genet., 83(8): 947-955.

SHERWOOD J.L., 1993 - Applied aspect of plant regeneration, pp. 135-138. - In: DiXON D.A., and R.A. GONZALES (eds.) Plant cell culture. A practical approach. Oxford University Press, USA.

SOKAL R.R., SNEATH P.H.A., 1963 - The principles and practice of numerical taxonomy. - Taxon, 12(5): 190-199.

TANDON H.L.S., 2005 - Methods of analysis of soils, plants, water, fertilizers and organic manure. - FDCO, New Delhi, India, pp. 203.

USHA P.K., BENJAMIN S., MOHANAN K.V., RAGHU A.V., 2007 - An efficient micropropagation system for Vitex negundo L., an important woody aromatic medicinal plant, through shoot tip culture. - Res. J. Bot., 2: 102107.

WALTON M., 1993 - Molecular markers: which ones to use? - Seed World, pp. 23-29.

WILLIAMS J.G., KUBELIK A.R., LIVAK K.J., RAFALSKI J.A., TINGEY S.V., 1990 - DNA polymorphisms amplified by arbitrary primers are useful as genetic markers. - Nucleic Acids Res., 18(22): 6531-6535.

WITHERS L.A., 1995 - Collecting in vitro for genetic resources conservation. - Collecting plant genetic diversity. CAB International, Wallingford, UK, pp. 511-515.

ZHAO T., ZHANG J., LIANG L., MA Q., CHEN X., ZONG J., WANG G., 2015 - Expression and functional analysis of WRKY transcription factors in chinese wild hazel, Corylus heterophylla Fisch. - PLoS One, 10(8): e0135315. 